\title{
Ecotourism and sustainability in community-driven ecological restoration: case studies from New Zealand
}

\author{
D. M. Campbell-Hunt \\ Department of Geography, Otago University, New Zealand
}

\begin{abstract}
Funding the conservation and restoration of protected natural areas is a challenge in many countries and contexts. This is especially so where the initiative has been taken by a community group that lacks guaranteed long-term access to a source of operating income. Such groups may initiate tourist operations in order to provide ongoing revenue for ecosystem protection and restoration. Can tourism fund the protection and restoration of an indigenous ecosystem? How can tourism be managed so that it does not impact negatively on ecosystem protection? This paper addresses these questions using case study research from New Zealand, a country facing important conservation issues and where tourism is a major component of the economy. The research comprises six case studies in which exclusion fencing has been used to protect indigenous New Zealand forest ecosystems from the impacts of alien pest mammals. In five of the six cases a community-based charitable trust is driving the project. Data analysis is at an early stage, but some interesting themes are emerging. Tourism is valued by these groups because of the education and advocacy opportunities it offers, as well as for its potential financial contribution. Thus these groups are prepared to meet the additional costs of creating a tourist operation, although this can give rise to philosophical tensions when organisational members are motivated primarily by ecological outcomes. The financial potential of tourism is perceived as location-sensitive; only two of these case studies expect to achieve full financial self-reliance through tourism. The ecological risks of tourism are seen as manageable through such tools as ecological management zones.
\end{abstract}

Keywords: New Zealand case studies, ecological restoration, community-driven, sustainability, tourism, ecological management zones. 


\section{Introduction}

The relationship between tourism and protected areas is a complex one. Tourism to areas of ecological value (often called ecotourism) is a potential means of supporting the conservation of local ecosystems and promoting sustainable local development (Ross and Wall [1]). In a developing nation context ecotourism can provide livelihoods for locals and thus redirect communities away from ecologically damaging activities, such as felling forest and harvesting wildlife (Naumes and Kammermeyer [2]). A study of the use of enterprise strategies in Asia and the Pacific concluded that ecotourism and other non-exploitative forest uses, such as the extraction of plant oils and forest fruits, can make a major contribution to the costs of ecosystem protection, thereby reducing the level of external funding required from governments and NGOs (Salafsky et al [3]). Similarly in developed nations tourism is widely used as a source of funds for biodiversity protection. The financial contribution expected of ecotourism varies; in a not-for-profit context it may simply decrease the level of funding required from non-commercial sources (such as philanthropic trusts and government funds). By contrast the development of an ecotourism business within the forprofit context is seen as serving both ecological and economic goals [4,5].

The future of global biodiversity rests not only in the protection of existing natural ecosystems, but also in ecological restoration, which has been defined by the Society for Ecological Restoration [6] as "the process of assisting the recovery of an ecosystem that has been degraded, damaged or destroyed." Ecological restoration often entails the elimination or control of harmful exotic species and the deliberate reintroduction of native species that have been lost from an area. The ecosystem restoration movement has captured the enthusiasm of ecologists, resource managers and the public in many parts of the world, and has led to the involvement of numerous non-governmental agencies and the donation of countless hours by citizen volunteers (Clewell and Aronson [7]). Restoration is a long-term commitment of land and resources; a restored ecosystem often requires ongoing human management to counteract the invasion of opportunist species, the impacts of various human activities, climate change and other unforeseeable events [6]. Thus a citizen initiative to undertake ecological restoration must address the issue of generating funds to both initiate and sustain the project. Ecotourism has a potential role to play in this context.

This paper reports on a research project currently in progress in New Zealand, where community groups are undertaking ecological protection and restoration projects in different locations around the country. These projects have a strong element of ecotourism. Restoration groups welcome visitors because project goals encompass education and advocacy as well as ecosystem protection. Tourism is also seen, to varying degrees, as an opportunity to generate operating revenue. The purpose of this paper is to describe how the community groups undertaking these projects perceive the relationship between tourism and ecosystem protection, and how they manage that relationship. 


\section{The research setting}

New Zealand is an island state that offers a poignant case study of the impact of human activity on biodiversity. Isolated from other land masses for 80 million years, New Zealand developed a highly distinctive endemic flora and fauna featuring diverse birds and reptiles but no mammals, apart from three species of small bat. There are an estimated 80,000 species of native plants, animals and fungi and a large proportion of these species do not occur naturally anywhere else on Earth, Ministry for the Environment [8]. New Zealand was one of the last places on Earth to be settled by humans, with indigenous peoples arriving from elsewhere in the Pacific about 900 years ago, and a major colonization by British settlers in the $19^{\text {th }}$ century. This comparatively recent invasion has had a dramatic impact on indigenous biodiversity; New Zealand has experienced one of the highest species extinction rates in the world and currently almost 2500 of native land-based and freshwater species are listed as threatened [8]. The two main drivers of biodiversity loss have been habitat change and introduced mammalian species. The latter (which include rats, mice, hedgehogs, mustelids, rabbits, cats, possums, deer and goats) destroy native flora and fauna through browsing, direct predation and competition for food. Habitat loss has stabilized, with just over $32 \%$ of New Zealand's land area protected for conservation purposes, but the effect of introduced pest species is ongoing.

The most effective way to protect indigenous flora and fauna in New Zealand is by the creation of natural environments that are free of introduced pest mammals, a strategy that has been widely employed on New Zealand's offshore islands. The creation of such environments on mainland New Zealand, through intensive pest control and/or the use of pest-exclusion fencing, is a more recent phenomenon. This research focuses on biodiversity restoration projects that use pest-exclusion fences. Exclusion fencing is an ambitious approach to ecosystem protection and restoration because of the high establishment costs (the fence design in common use costs around \$NZ200,000 per kilometer, depending on the specifics of the terrain) and the need for a long-term commitment to fence maintenance, repair and eventual replacement. Furthermore, a pest-free ecosystem in the current New Zealand landscape is an anomaly and calls for vigilant monitoring of the pest-free status of the sanctuary and the capacity to respond rapidly and effectively to reinvasions by mammalian pests. The restoration of a healthy ecosystem that is naturally authentic to the site usually encompasses the return of species that are known to have become locally extinct, many of which are now nationally threatened or endangered. Their translocation to a sanctuary requires commitment to their appropriate care in the short and long term. Despite these challenges, fenced sanctuaries are growing in number and capturing the imagination of communities throughout the country. The financial demands of sanctuary operation, together with high profile of tourism in the New Zealand economy, mean that tourism is commonly chosen as an opportunity for revenue generation. Thus New Zealand offers an excellent context for case study research on the growing global phenomenon of ecological restoration and the potential contribution of tourism to sustaining protected areas. 


\section{Methodology}

\subsection{Case studies}

The concept of fenced pest-free sanctuaries on mainland New Zealand arose in the late 1990s, and the past ten years have seen the initiation of around twenty sanctuary projects, most of them by individual or groups outside of the government sector. The six case studies chosen for this research are ecological restoration sanctuaries with a strong community involvement, as evidenced by a formally constituted community-based organisation and extensive use of volunteers alongside paid staff. Five of the six are driven by a community-based charitable trust while the sixth is a joint initiative of a regional council and a community society. The case study sites are all at least 100 hectares in size and have completed pest-exclusion fencing. These criteria have constrained the variability of the cases, thereby offering some opportunity for comparability between cases. Nonetheless, differences remain in a range of variables, the first being the status of the land, which in five of the six case studies is either partially or wholly public land; land status in turn shapes the relationship between the community organisation and agencies of government. A second variable is stage of development. The oldest of the case studies has been operating a tourist business for eight years, but none of the others yet has steady tourist revenue. However, four of the six have an active education programme for schools. When data gathering was undertaken, only four had released rare native species back into their sanctuary. Table 1 summarises the case studies.

\subsection{Data sources}

The primary data are the transcripts of 50 semi-structured interviews with key people from each case study community organisation and associated government agency personnel. The analysis of documents (strategic plans, feasibility reports etc) generated by the case study groups provides additional data. Data analysis is in the early stages; the following findings are based on an initial analysis.

\section{Results and discussion}

\subsection{Tourism and financial sustainability}

At the top of almost all of the interviewees' minds when asked about the essential ingredients for sustaining the sanctuary in the long-term was the need to make ends meet financially. In the words of one interviewee:

"But the on-going issues really are coming down to dollars, and how we are actually going to generate that income...funding operating costs is a real challenge...once you get into that inevitable on-going grind of year in, year out funding, then there's only a limited amount of community resources available and other good projects come up...So I think it's imperative that we establish, as quickly as we can, our own income streams." 
Table 1: Description of six case study sanctuaries.

\begin{tabular}{|c|c|c|}
\hline $\begin{array}{l}\text { Name of sanctuary } \\
\text { (and community } \\
\text { organisation) }\end{array}$ & $\begin{array}{l}\text { Land ownership, government } \\
\text { relationship and forest status }\end{array}$ & $\begin{array}{l}\text { Stage of development } \\
\text { (April 2008) }\end{array}$ \\
\hline $\begin{array}{l}\text { Orokonui } \\
\text { Ecosanctuary } \\
\text { (Otago Natural } \\
\text { History Trust) }\end{array}$ & $\begin{array}{l}230 \text { hectare of public conservation } \\
\text { land plus } 85 \text { hectare of Trust- } \\
\text { owned land. Formal authority to } \\
\text { control and manage conservation } \\
\text { land has been transferred from the } \\
\text { Department of Conservation to } \\
\text { the Trust for } 50 \text { years. } \\
\text { Young regenerating forest with } \\
\text { stands of exotic species. } \\
\text { Urban location. }\end{array}$ & $\begin{array}{l}\text { Fence completed in 2007. Pest } \\
\text { eradication almost complete. } \\
\text { Extensive replanting and wetland } \\
\text { creation is underway. The first } \\
\text { bird and reptile species } \\
\text { reintroductions are in preparation. } \\
\text { Breeding aviaries installed on site } \\
\text { are currently housing native } \\
\text { parrots previously absent from the } \\
\text { site. }\end{array}$ \\
\hline $\begin{array}{l}\text { Karori Wildlife } \\
\text { Sanctuary } \\
\text { (Karori Wildlife } \\
\text { Sanctuary Trust) }\end{array}$ & $\begin{array}{l}252 \text { hectare of Wellington City } \\
\text { Council land leased to the Trust. } \\
\text { Young regenerating forest with } \\
\text { stands of exotic species. } \\
\text { Urban location. }\end{array}$ & $\begin{array}{l}\text { Fence completed in } 1999 . \text { All } \\
\text { pests eradicated except mice. } \\
\text { Extensive replanting and wetland } \\
\text { creation. } \\
\text { Breeding populations re- } \\
\text { established of many indigenous } \\
\text { birds, reptiles, amphibians, } \\
\text { insects. } \\
\text { Approx. } 60,000 \text { visitors per year. } \\
\text { Active education programme. }\end{array}$ \\
\hline $\begin{array}{l}\text { Bushy Park } \\
\text { (Bushy Park } \\
\text { Homestead and } \\
\text { Forest Trust) }\end{array}$ & $\begin{array}{l}100 \text { hectares of private land, } \\
\text { including an Edwardian } \\
\text { homestead; gifted to NZ Forest \& } \\
\text { Bird in } 1963 . \\
\text { Full area is managed by the Trust. } \\
\text { Pocket of ancient forest } \\
\text { surrounded by farmland. }\end{array}$ & $\begin{array}{l}\text { Fence completed } 2005 . \\
\text { Pest eradication complete. } \\
\text { Three native bird species have } \\
\text { been reintroduced and } \\
\text { successfully established. } \\
\text { Active education programme. }\end{array}$ \\
\hline $\begin{array}{l}\text { Rotokare Scenic } \\
\text { Reserve } \\
\text { (Rotokare Scenic } \\
\text { Reserve Trust) }\end{array}$ & $\begin{array}{l}220 \text { hectares of Scenic Reserve, } \\
\text { vested in the South Taranaki } \\
\text { District Council. } \\
\text { Free public entry is a condition of } \\
\text { reserve status. } \\
\text { Rural pocket of ancient forest } \\
\text { surrounded by farmland. }\end{array}$ & $\begin{array}{l}\text { Fence nearly completed. } \\
\text { Pest eradication planned for } 2008 \text {. } \\
\text { No reintroductions have been } \\
\text { made, but pre-fence pest control } \\
\text { work has led to some natural re- } \\
\text { colonisation. }\end{array}$ \\
\hline $\begin{array}{l}\text { Maungatautari } \\
\text { Ecological Island } \\
\text { (Maungatautari } \\
\text { Ecological Island } \\
\text { Trust) }\end{array}$ & $\begin{array}{l}3400 \text { hectares, of which two- } \\
\text { thirds is a Scenic Reserve vested } \\
\text { in the Waipa District Council. } \\
\text { The remainder is land owned by } \\
\text { local farmers and Maori } \\
\text { (indigenous peoples). } \\
\text { Rural pocket of ancient forest } \\
\text { surrounded by farmland. }\end{array}$ & $\begin{array}{l}\text { Fence ( } 47 \mathrm{~km} \text { long) completed in } \\
2006 . \\
\text { Enclosures of } 30 \text { hectares and } 70 \\
\text { hectares fenced in } 2004 . \\
\text { Pest eradication almost complete. } \\
\text { Three reintroductions of bird } \\
\text { species to date and more are } \\
\text { planned. } \\
\text { Active education programme. }\end{array}$ \\
\hline $\begin{array}{l}\text { Tawharanui Open } \\
\text { Sanctuary } \\
\text { (Tawharanui Open } \\
\text { Sanctuary Supporters } \\
\text { Inc) }\end{array}$ & $\begin{array}{l}550 \text { hectares owned by the } \\
\text { Auckland Regional Council and } \\
\text { managed as a Regional Park. } \\
\text { Community group provides } \\
\text { substantial voluntary labour input } \\
\text { and fundraising. Joint Technical } \\
\text { Working Group sets operational } \\
\text { priorities. }\end{array}$ & $\begin{array}{l}\text { Fence completed in } 2004 . \\
\text { Pest eradication has not been } \\
\text { complete; mice and rabbits } \\
\text { remain, and reinvasion by other } \\
\text { pests is a constant risk, due to } \\
\text { peninsula situation. }\end{array}$ \\
\hline
\end{tabular}


Table 1: $\quad$ Continued.

\begin{tabular}{|l|l|l|}
\hline $\begin{array}{l}\text { Name of sanctuary } \\
\text { (and community } \\
\text { organisation) }\end{array}$ & $\begin{array}{l}\text { Land ownership, government } \\
\text { relationship and forest status }\end{array}$ & $\begin{array}{l}\text { Stage of development } \\
\text { (April 2008) }\end{array}$ \\
\hline & $\begin{array}{l}\text { Peninsula with adjacent marine } \\
\text { reserve. Land cover is a mix of } \\
\text { old forest, wetland and pasture. } \\
\text { Within easy drive of NZ's largest } \\
\text { city. }\end{array}$ & $\begin{array}{l}\text { Extensive weed control work, } \\
\text { replanting and wetland creation. } \\
\text { Successful reintroductions of four } \\
\text { native birds and reptiles. } \\
\text { Active education programme. }\end{array}$ \\
\hline
\end{tabular}

For five of the six sanctuaries tourism is seen as an important tool in generating that income stream. The only sanctuary that is not planning to charge for tourist experiences is Tawharanui Open Sanctuary, where the regional council pays operating income and is committed to free public access.

At the time of the research only one sanctuary, Karori Wildlife Sanctuary, had actively developed tourism as a source of income. Karori was fenced in 1999 and opened for visitors in 2000; revenue from ecotourism comprises only $30 \%$ of current operating revenue $(2006 / 2007$ year). The remainder comes primarily in the form of an operating grant from the Wellington City Council, which owns the land. Nonetheless Karori Wildlife Sanctuary Trust intends to achieve financial self-reliance through tourism. It aims to boost visitor numbers from the current 60,000 to 200,000 per annum, using a new visitor reception and education centre as a major marketing tool.

Whether a sanctuary trust adopts a tourism strategy for financial sustainability is shaped by whether the governance team perceives that the sanctuary is wellplaced geographically. Karori Wildlife Sanctuary is an urban sanctuary in the middle of the capital city of New Zealand. Orokonui Ecosanctuary is in Dunedin, a city that is already a popular destination for ecotourism due to the presence of rare species of penguin, sea-lion and albatross. Hence the Otago Natural History Trust is confident that it will be able to attract sufficient tourist numbers for financial self-reliance. Where a sanctuary is in a rural area proximity to an important tourist route encourages a tourism strategy, as in the case of the Maungatautari Ecological Island which is accessed from the road between two major tourist attractions in the North Island. In this case, however, operating income may need topping-up from sources other than tourism.

Two of the case study sanctuaries are, by contrast, neither urban nor close to a major tourist route, these being Rotokare Scenic Reserve and Bushy Park. In both cases there is recognition that tourism will provide only a minor proportion of operating revenue. In the case of Bushy Park lease income is generated by an historic homestead that is run as an independent hotel business. Free public entry is a condition of scenic reserve status and this is an added challenge for the Rotokare Scenic Reserve Trust. The Trust may, however, charge for value-added products such as tours. In addition a joint management agreement is being negotiated with the South Taranaki District Council, with the expectation that the Council will meet some of the operating costs. 


\subsection{Tourism and tension}

One of the challenges of adopting a tourism strategy for generating income is the associated increase in capital and operating costs. Tourism entails the creation and maintenance of facilities such as tracks, toilets and a visitor centre for shelter, educational displays and the collection of payments. Interviewees from all case studies, when asked what motivates them to be involved, identified a strong drive to protect and restore native flora and fauna, commonly in an area that is close to where they live and often a landscape that has important meaning for them. For some community members there is a philosophical tension between these ideals and the creation of a tourist business:

"There are some members who are philosophically uncomfortable with some of the more commercial aspects of what the board does, and would probably be happier to see a lean-to visitor centre and all the resources poured into conservation."

"It's probably the thing that the sanctuary trust board talks about more that anything else... is how far do we go down the tourism line."

Only one of the case study sanctuaries (Orokonui Ecosanctuary) has attempted, in its feasibility study, to estimate the difference in operating costs between a "restoration-only" scenario and a "restoration plus visitation" scenario. Providing for visitors was estimated to double the operating costs. The same cost multiplier is expected by the Karori Wildlife Sanctuary Trust as a result of the new visitor centre and the resultant increase in visitor numbers. Sanctuary groups are willing to meet these extra costs not only because they are optimistic that it is the route to partial or complete financial self-reliance, but also because they are committed to visitor education and the advocacy outcomes it offers.

"If we can tell the stories and let other people know what we have done and what we can do to change things for the better. That's a really important role for the sanctuary... being able to encourage other people to support it and think 'what can I do?',

\subsection{Tourism and ecosystem sustainability}

When asked whether they saw any tensions between increasing public use of their sanctuary and its ecological well-being, none of the respondents perceived this as a problem that could not be dealt with through management. A relative lack of concern about overuse may be a function of the newness of these projects and their keenness to generate tourist numbers for financial income.

"If the numbers go through the roof, if we end up with 500,000 people wanting to visit a year, then you've got a problem but most people would go, hey fantastic problem, we have too many people wanting to come. You can always manage your way around that."

"I think it is vital that we do have increased use in order to generate some revenue...I don't think there is any real issue there beyond managing that reinvasion risk."

The management of entry points and the development of ecological management zones are the main strategies for managing the impacts of visitors. 


\subsubsection{Management of entry points}

Public entry points increase the risk of pest reinvasion. Three of the sanctuaries are at a disadvantage in this respect because public access is by vehicle. Tawharanui Open Sanctuary has a single vehicle gate system, and as there is a campground inside the sanctuary, visitor vehicles commonly have trailers containing equipment that may harbour pests. This sanctuary faces greater risks of reinvasion than any of the other five, not only because of vehicle access, but also because it is a fenced peninsula and pests can swim around the ends of the fence. Rotokare Scenic Reserve Trust and Bushy Park Trust have each installed a double vehicle gate system at their sanctuaries, thereby decreasing the chance of pest mammals entering the sanctuary as a vehicle passes through. The Bushy Park Trust has built an additional rodent-proof fence around the area accessible by vehicles; in this way any mice or rats that enter with vehicles are prevented from moving into the forested sanctuary area. The other three case study sanctuaries have pedestrian access only, commonly a double gate system. Visitors are required to search their bags on entry, and at Karori Wildlife Sanctuary mice have been found in visitor bags on several occasions.

\subsubsection{Ecological management zones}

All of the sanctuaries have areas of high public use and areas that are to remain comparatively undisturbed, although the case studies vary in the extent to which these differences are formalised within a management plan. Areas close to the main public entrance are developed for visitor use, with high quality tracks and track-side interpretation panels. Less accessible areas are left undeveloped to serve as wildlife retreats. The larger sanctuaries also provide a range of track grades to cater for those who want longer walks or more remote experiences. These kinds of tourists are expected to be a much smaller proportion of the visitor numbers than those who want a half hour or hour walk close to the entrance point. Clearly-marked tracks discourage visitors from wandering off the path and damaging the undergrowth or disturbing ground-nesting birds.

At the Maungatautari Ecological Island (the largest sanctuary at 3400 hectares), two smaller enclosures fenced in 2004 are intended as the focus of the tourist experience.

"That's the reason we set both of the enclosures up alongside of the main entry points, just so that we can try and manage people and do a controlled area, and leave the mountain as much as we can to its own devices."

The Maungatautari Ecological Island Trust has successfully negotiated a special bylaw that will enable it to enact a gate charge for these enclosures, as in general a scenic reserve must offer free public access. At the Orokonui Ecosanctuary the Otago Natural History Trust intends to leave the entire eastern side of the valley as a research and wildlife zone, with no public access. The Rotokare Scenic Reserve has a single walking track that skirts the central lake, leaving the slopes of the catchment comparatively undisturbed. At Bushy Park visitors can access only a small central portion of the forest.

The Karori Wildlife Sanctuary Trust has developed the concept of ecological management zones more fully than any of the other case studies and these form 
the basis of its management plan (Figure 1). The main entry and area of high public use is Zone 1; a road-standard track takes visitors along the valley floor where interpretation panels focus on visitor education. Well-developed tracks in zones 2, 4 and 6 provide further walking opportunities for fitter visitors. Zones 3 and 7 are untracked and are managed for conservation only. Zone 5 offers a remote self-guided visitor experience, consistent with a focus on conservation.

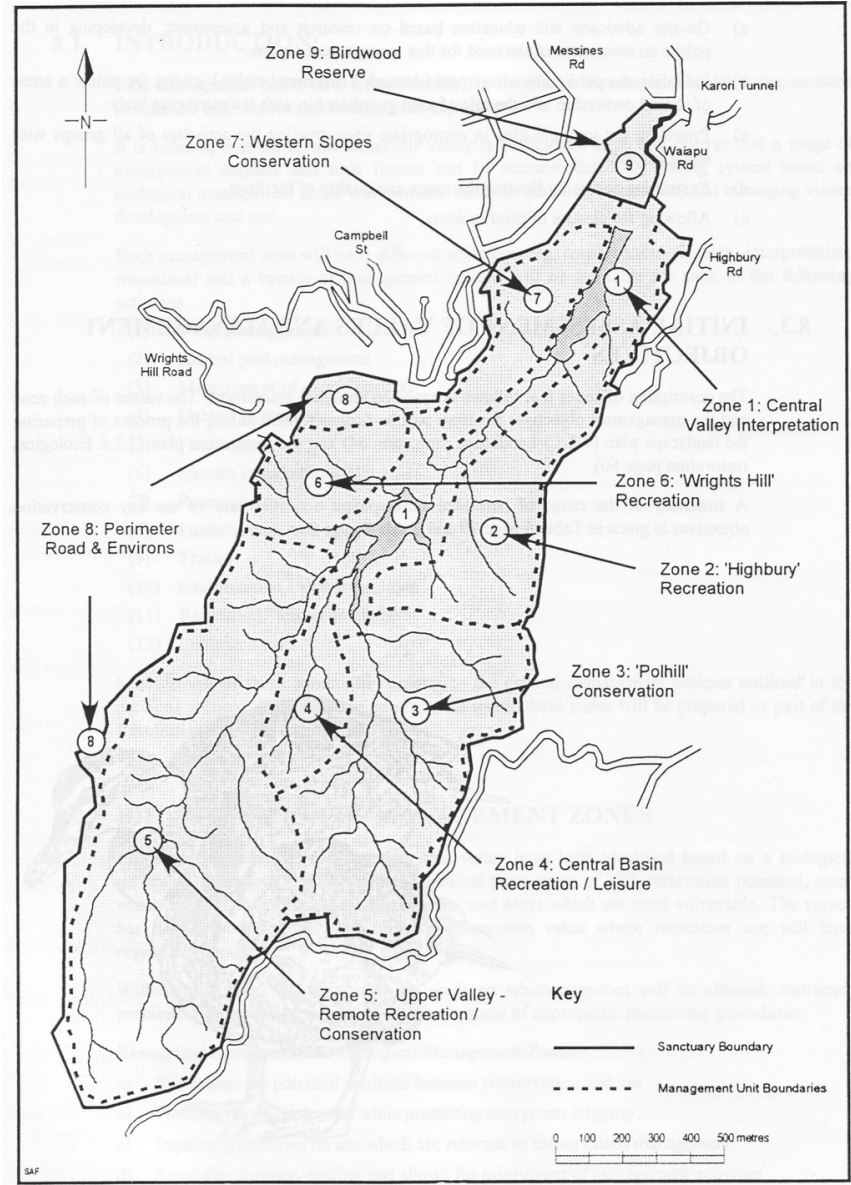

Figure 1: Ecological management zones at the Karori Wildlife Sanctuary [9].

\section{Conclusion}

The complex relationship between tourism and the sustainability of communitymanaged protected areas is a global issue that is informed by these New Zealand case studies. An initial analysis of the research data indicates that tourism to protected areas is valued as a source of operating revenue and also as an 
opportunity to inform and educate, and thus advocate for conservation. However, developing a tourist operation can create philosophical tensions within a community organisation. In addition tourism increases costs and brings ecological risks, including pest reinvasion. The consequent need to balance financial, social and ecological considerations is common to all six case studies. Although all have chosen to develop visitor facilities, the expected financial contribution of tourism varies and is seen as location-sensitive. Revenue strategies are also shaped by land status and the relationship with government agencies. Although there are variations in the detail, all case studies focus on the management of visitor entry points to decrease the risks of pest reinvasion, and all employ some form of management zoning to control visitor use of the area.

\section{References}

[1] Ross, S. \& Wall, G. Ecotourism: towards congruence between theory and practice. Tourism Management 20, pp123-132, 1999.

[2] Naumes, M.J. \& Kammermeyer, J.A. Sustainable Harvest International: creating local ecopreneurs. Making Ecopreneuers: Developing Sustainable Ecopreneurship, ed M. Schaper, Ashgate Publishing Limited: Hampshire, England, pp 239-251, 2005.

[3] Salafsky, N., Cauley, H., et al. A systematic test of an enterprise strategy for community-based biodiversity conservation. Conservation Biology 15(6), 1585-1595, 2001.

[4] Geneste, L. Hong Kong Dolphinwatch: the evolution of an ecopreneurial business venture. Making Ecopreneuers: Developing Sustainable Ecopreneurship, ed M. Schaper, Ashgate Publishing Limited: Hampshire, England, pp 203-213, 2005.

[5] Volery, T. Earth Sanctuaries limited: an entrepreneur commercializes conservation. Making Ecopreneuers: Developing Sustainable Ecopreneurship, ed M. Schaper, Ashgate Publishing Limited: Hampshire, England, pp 214-223, 2005.

[6] Society for Ecological Research. The SER Primer on Ecological Restoration. Science and Policy Working Group, Society for Ecological Restoration International: Tuscon, www.ser.org, 2004.

[7] Clewell, A.F. \& Aronson, J. Motivations for the restoration of ecosystems. Conservation Biology 20(2), pp 420-428, 2006.

[8] Ministry for the Environment. Environment New Zealand 2007. New Zealand Government: Wellington, New Zealand, 74 pages, 2007

[9] Karori Wildlife Sanctuary Trust Management Plan: Reclaiming the Mainland. January 2007 